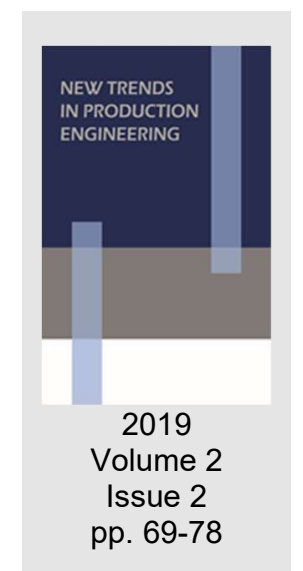

\title{
The Economic Aspect in Improving the Production Process
}

\author{
Monika Górska, Marta Daroń \\ Czestochowa University of Technology, Poland
}

Volume 2

Issue 2

pp. $69-78$

Date of submission to the Editor: 09/2019

Date of acceptance by the Editor: 11/2019

\section{INTRODUCTION}

In recent years, managers have departed from focusing on the functioning of individual departments of the company. This approach has been replaced by a process approach - attention is paid to streamlining processes, in particular key processes. There are a number of different possible methods of improvement applicable to selected areas of the functioning of enterprises and even more - to the processes taking place in these units. In the publication there was presented a case study - on the basis of a chosen company and its chosen production process - it was presented how the selected improvement methods can be used. Moreover, the effects of introducing specific corrective actions along with an indication of the benefits achieved were also presented. The aim of the study was to identify areas in the bearing production process that contribute to the problems, and then demonstrate that the implementation of appropriate methods of identification and improvement in these areas may contribute to the improvement of production processes, elimination of existing defects and to cost reduction. Therefore, in order to achieve the goal of the study, the research took place in several stages and there were used two methods $-5 \mathrm{WHY}$ and FMEA. Moreover, in order to indicate the actual effects in the form of a decrease in the number of production defects and re-estimation of the level of costs of possible defects after the introduction of corrective actions, the study was spread over time.

The main research hypothesis put in the work was: HO: The use of selected methods of improving the production process affects its efficiency. Specific hypotheses were: $\mathrm{H} 1$ : The use of selected methods of improving the production process reduces the occurrence of detected defects $\mathrm{H} 2$ : The use of selected methods of improving the production process influences a cost reduction of process defects correction and achieving savings.

The detailed objectives of the study were as follows: C1. Quantity verification regarding detected defects after the introduction of selected methods of improving the production process $\mathrm{C} 2$. Value verification of costs caused by 
defects after improvements. C3. Verification of the reasonableness of introducing improvements by means of selected methods for the analyzed production process.

\section{METHODOLOGY OF RESEARCH}

Improvement activities in every enterprise should focus primarily on strategic processes for a given activity. For the enterprises of the metal industry, the production processes concerning mainly the main assortment will be strategic processes. Improvement of production processes is possible only after a thorough analysis of the process itself (Ilés et al., 2017). In the paper, due to the volume framework, the attention was focused on the selected stage of the manufacturing process of one of the main products. The literature contains many studies thematically related to process improvement. For example, Ulewicz and others (Ulewicz et al.,2015) had undertaken an attempt to assess the functioning of the production control systems based on the analysis of selected companies of widely understood metal industry. Another example is the use of the Glenday's probing method to identify the correct area that requires value stream mapping and areas called excessive complexity that do not provide added value (Ulewicz et al., 2016). In turn, M. Mazur presents how to effectively use company resources by identifying the value stream and eliminating all processes that do not contribute to the company's added value (Mazur, 2016). Many other specific improvement tools are also used for production processes. There are also many examples of their usage in scientific literature, such as: SMED (Single Minute Exchange of Die), FMEA (Failure Mode and Effects Analysis), 5S method, Poka Yoke (ex. Baskiewicz \& Kadłubek, 2017), 5W2H method (Nowakowska \& Ingaldi 2016) or other. In the era of widely understood and used actions for the improvement of production processes, the introduction of specific methods or techniques may, contrary to appearances, give managers many difficulties. While the knowledge of methods is no longer a problem among the managerial staff, choosing the right ones and implementation of them into a dedicated problem is sometimes a challenge. Moreover there is limited number of scientific papers which present real effects of improving a process in a long term or which examine the results of improvement in the next period.

To cover the gap in this knowledge, authors prepared the research which was founded on the chosen company. The choose of the entity was purposeful what was involved with the possibility of carrying the deeply analysis spread in the time of few months.

The analyzed enterprise is a leading manufacturer of various types of rolling bearings. The company offers its products both to the domestic market and to European markets. The company has implemented a Quality Management System in the field of bearing production and specialized tools that meets the requirements of the ISO 9001:2008 standards.

Due to the fact that the surveyed enterprise operates on the basis of the adopted Quality System, it is not foreign to the tools used to provide it. However, despite the use of selected tools and techniques to improve the manufacturing process, 
such as: Kaizen, 5S, Pareto, ABCD, Ishikawa, there is an increase in defective products - bearing rings.

Defective production of this product generated costs and losses in the company. Some of the resulting defects were detected already during the production process at certain stages. Unfortunately the greater part of defects was detected by the customer. Two methods: 5 Why and FMEA were used to indicate areas contributing to occurrence of defects. There are shown the stages of the study on Fig. 1.

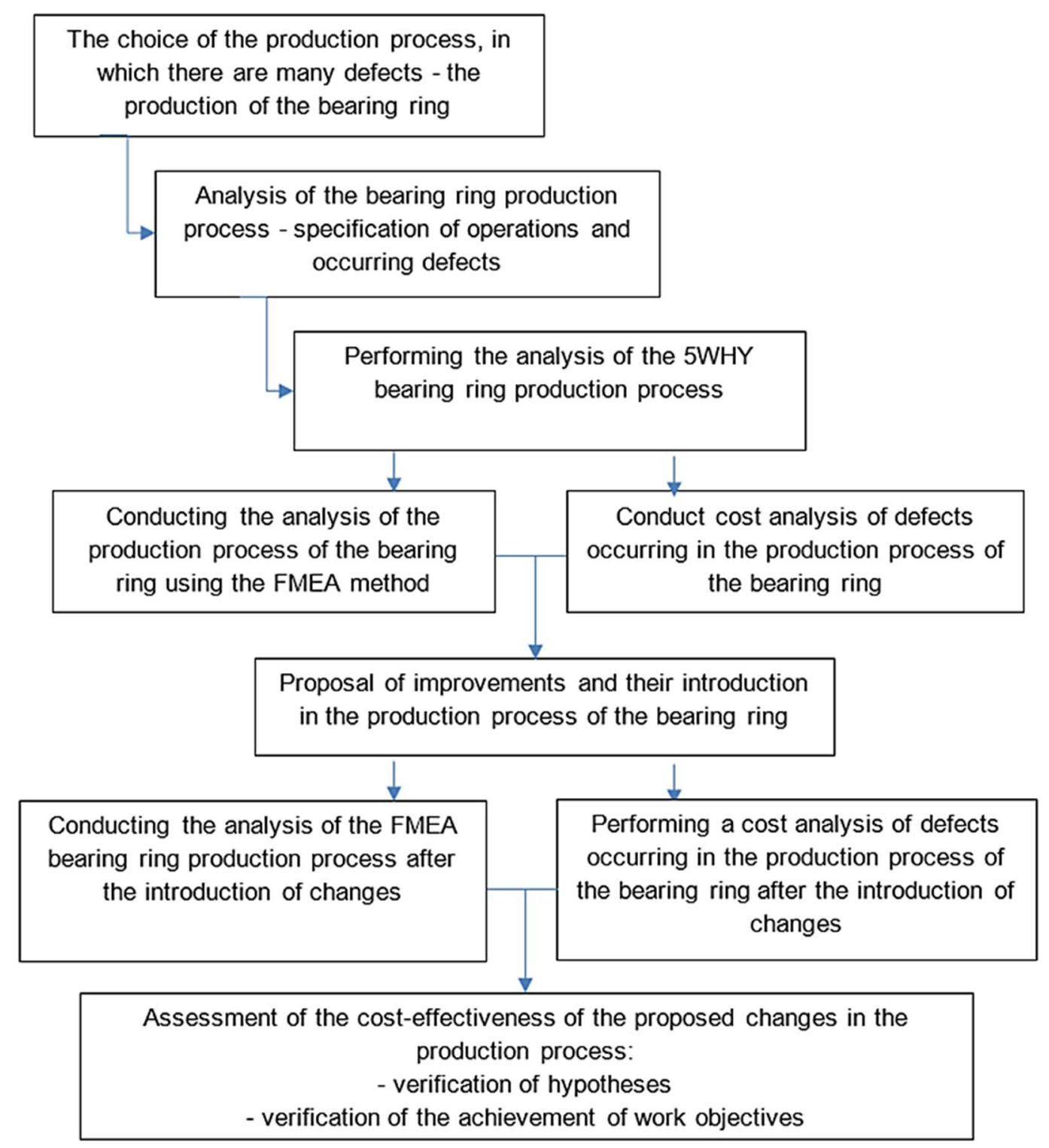

Source: own study

Fig. 1 Diagram of the investigation procedure

First, the analysis of the selected production process was carried out, indicating the stages and operations in which the defects are noted. Then a 5WHY analysis was carried out, the interpretation of which is presented in the third paragraph of the paper. The next step of the research work included the use of the FMEA method, which was carried out twice: before and after the introduction of changes in the production process of the bearing ring. The results of this part of 
the study are presented in the fourth point of the publication. The adopted procedure made it possible to validate the assumed work hypotheses.

\section{AN ANALYSIS OF THE SELECTED PROCESS - 5WHY RESULTS}

By occurring problems, the identification of areas of defects was carried out along with the analysis of the reasons for their occurrence. There were presented the results of the analysis of the manufacturing process of the bearing ring, which allowed to identify the main operations and occurring defects (Fig. 2).

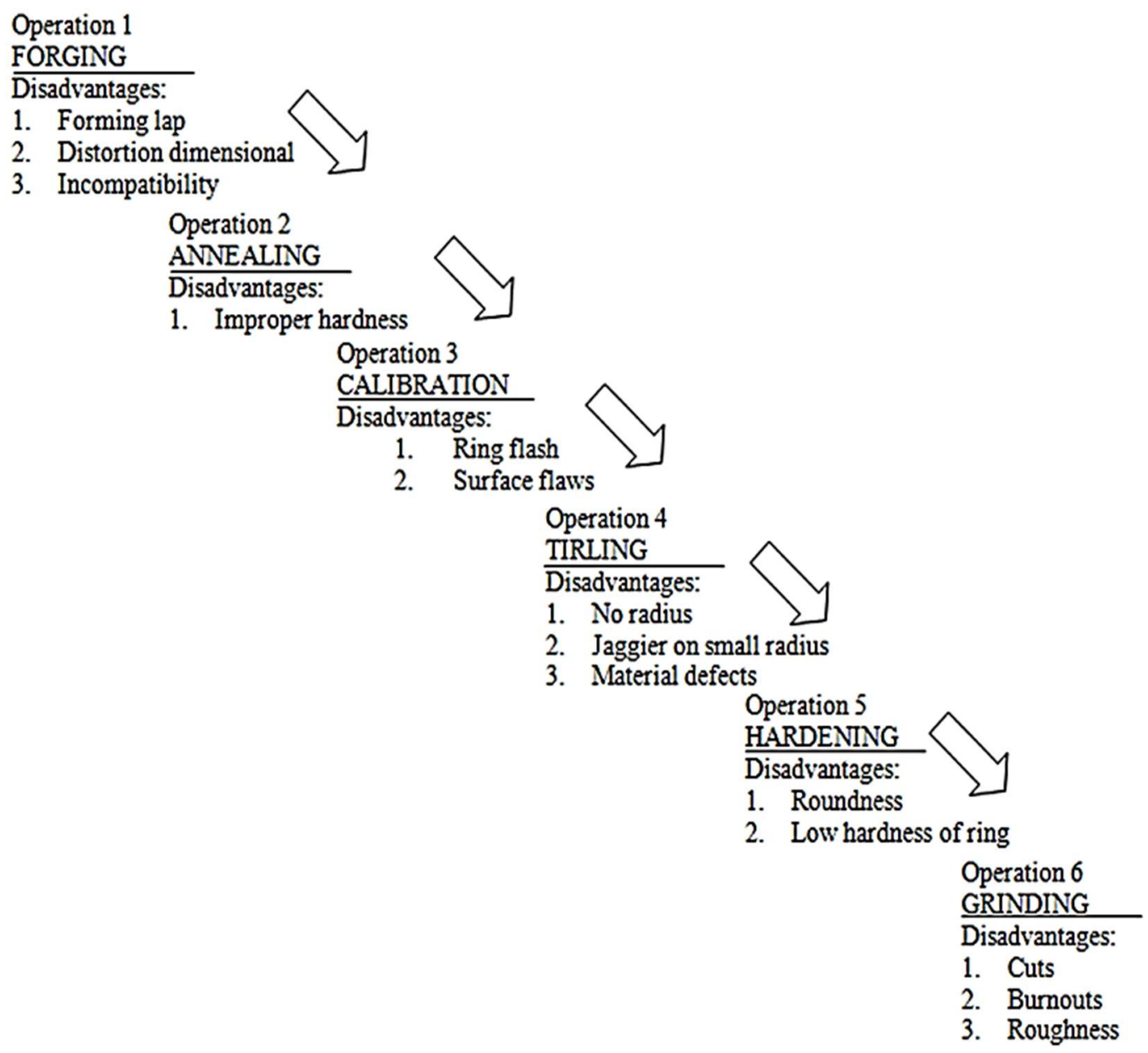

Source: own study

Each of the defects occurring in individual operations was subjected to a separate analysis using the $5 \mathrm{WHY}$ method. The application of this instrument was aimed at identifying and assessing potential disruptions to this stage of the process, and thus identifying the areas that particularly required the development of corrective and preventive actions or the development of new work standards for selected operations. Unfortunately, it was not possible to describe in detail the whole analysis according to the 5WHY method for so many defects in the above-mentioned operations. Therefore, in the further part of the paper, the main attention was paid to present only the main causes of the defects that most often were occurring in the analyzed process. 
It turned out that already in the first phase of the manufacturing stage there are defects regarding, among others: material forging. The reason for the occurrence of the shackled metal defect in the researched item was incorrect setting of the machine, which was used in the forging operation. This caused that the product was defective. Another defect (the only one in operation No. 2), which was analyzed by the $5 \mathrm{WHY}$ method, was the inadequate hardness of the tested product. In this case, the impact on the occurrence of defect could have such factors as: incorrectly set process of annealing and exceeded curing temperature, and lack of protective atmosphere. In the third operation, the most common defect was the ring flash. Using the $5 \mathrm{WHY}$ method, the reasons for its occurrence were identified, which was the inappropriate placement of the material and excessive amount of the material, which could cause uneven distribution of processed parts. The reasons for the defect may be attributed to the insufficient number of training for employee which was responsible for this part of the process. However, at the stage of the operation 4 the cause of the defect - lack of radius - was the wrong setting of the machine by the operator during the measurement of the radius. In turn, the basic cause of inadequate cuts of the surface (the most common defect in operation 6) was the unsuitable quality of the abrasive granulate. In this case, the reason for the defect was the human factor - the wrong choice of the supplier of grinding materials (during selecting the supplier of abrasives, the price before the quality was mainly taken into consideration). In operation 6 a significant defect was also the burnout of the material, which was caused by the excessive speed of grinding.

\section{THE ECONOMIC DIMENSION OF CORRECTIVE ACTIONS FOR THE MAIN DEFECTS OF THE ANALYZED PROCESS}

In the next stage of process improvement, corrective actions were determined for the indicated defects. Using the FMEA method, the RPN indicator level for selected defects was calculated before the introduction of corrective actions and the RPN level after their introduction. What's more, the costs of these defects, costs of corrective actions, costs of defects after the introduction of corrective actions and savings resulting from the introduction of improvements were estimated.

The RPN index is the result of multiplication of such elements as: severity of the defect and the probability of occurrence of the defect, as well as the detection of the defect. It has been established for each defect. In Tab. 1 there was shown levels of RPN indexes for the most common defects before and after corrective actions. It was assumed that the RPN index should not exceed 70 for any of the defects, because in each other it would be necessary to introduce corrective actions. In the analyzed production process, the RPN indexes for the presented defects were much larger and ranged from 72 to 162 . Therefore, it was necessary to introduce corrective actions aimed at reducing RPN index levels. Corrective actions were proposed and taken on the basis of the results obtained from the 5WHY method. After the introduction of these measures, the RPN index 
was again calculated for defects, the causes of which were attempts to eliminate or reduce their occurrence.

Table 1 The analysis of the results of corrective actions based on 5WHY and FMEA

\begin{tabular}{|c|c|c|c|c|c|c|c|c|}
\hline 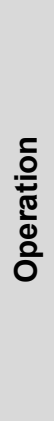 & Defect & 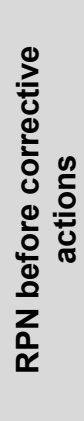 & 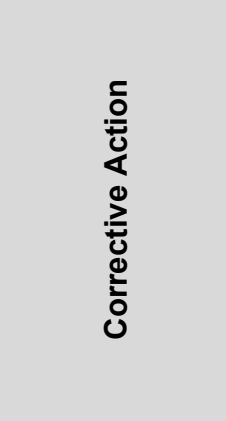 & 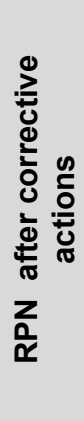 & 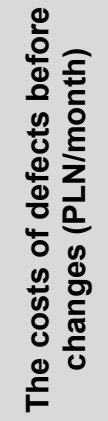 & 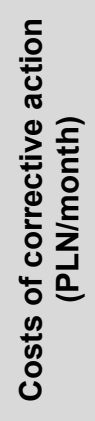 & 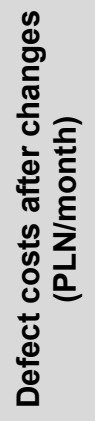 & 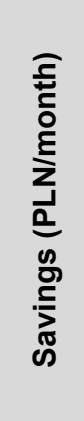 \\
\hline 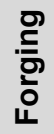 & $\begin{array}{c}\text { shackled } \\
\text { metal defect }\end{array}$ & 120 & $\begin{array}{c}\text { Staff training } \\
\text { by the } \\
\text { operator }\end{array}$ & 48 & 8000 & 300 & 3200 & 4500 \\
\hline 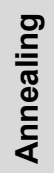 & $\begin{array}{l}\text { Incorrect } \\
\text { hardness }\end{array}$ & 60 & $\begin{array}{c}\text { Nitrogen } \\
\text { replacement } \\
\text { nozzles } \\
\text { for ceramic }\end{array}$ & 0 & 5000 & 2000 & 0 & 3000 \\
\hline 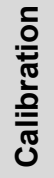 & $\begin{array}{l}\text { Beads } \\
\text { on rings }\end{array}$ & 72 & $\begin{array}{l}\text { Visualization } \\
\text { of defects } \\
\text { at the } \\
\text { workstation }\end{array}$ & 36 & 15000 & 300 & 7500 & 7200 \\
\hline$\stackrel{\text { 을 }}{\frac{E}{2}}$ & No radius & 72 & $\begin{array}{c}\text { Automation } \\
\text { of } \\
\text { measurements }\end{array}$ & 0 & 7500 & 1000 & 0 & 6500 \\
\hline 을 & Cuts & 162 & $\begin{array}{l}\text { Changing } \\
\text { the supplier } \\
\text { of grinding } \\
\text { stones }\end{array}$ & 61 & 7500 & 300 & 3000 & 4200 \\
\hline 을 & Burnouts & 72 & $\begin{array}{l}\text { Staff training + } \\
\text { visualization } \\
\text { of defects }\end{array}$ & 0 & 3500 & 300 & 0 & 2900 \\
\hline
\end{tabular}

To achieve the goal of the paper, there were not important the levels of individual components of the RPN index, but the level of RPN index in the context of the proposed corrective actions. For this reason, there were also placed the Tab. 1 columns in which the actual costs caused by selected defects and the costs of improvement actions and their effects in the form of real savings were presented. Analyzing the results of the conducted study, it can be concluded that the greatest risk of problems in the studied process was associated with abrasive activities (RPN = 162) and inserting (RPN =120). In the case of identification of a defect related to the abradation of material, the enterprise on the bais of the results obtained from the conducted analyzes has decided to 
change the procedure of supplier evaluation and selection. The existing supplier evaluation system required improvements due to the lack of clear criteria and an appropriate rating system. The employees focused mainly on: price, delivery date, completeness of delivery or checking the documentation containing approvals, certificate of inspection, confirmation of origin of materials, etc. Therefore, the aim of the improvement activities was the development and verification of a new system of supplier assessments, which allowed for a detailed assessment of suppliers in terms of: quality, price competitiveness, material availability and type of packaging. It is worth adding that the basic principle in the sphere of supply is the selection of reliable partners and developing cooperation for mutual long-term benefits. Thanks to the implemented assessment system of its contractors (the assessment consisted, among others, in the fact that in the event of non-compliance, the supplier is given negative points according to the adopted criteria) the company has the opportunity to cooperate with the best of them. The evaluation and selection of suppliers carried out in this way not only resulted in a decline in the RPN index from the level of 162 to the level of 61 in the last few months, but also reduced the bearing costs for non-compliance by $40 \%$. What is more, the involvement of the capital needed to implement improvement measures was not low in relation to the losses generated.

The introduction of additional training in the case of shackled metal defect resulted in a decrease of costs incurred on this account from PLN 8,000 to PLN 3,500 . For such defects as: incorrect hardness, lack of radius or scorching, the corrective actions introduced have completely reduced these discrepancies. The actions taken only in the case of these three defects have saved PLN 12,400 .

\section{DISCUSSION}

If the results of the assessment of processes are not satisfactory, processes improving processes should be undertaken. At the same time, these processes that are most important to clients should be improved all the time (Rampersad, 2004). Processes for improvement can also be selected by analyzing their value. It is characterized by the fact that the expenditure incurred on these processes and the results resulting from it are checked. This method can be applied to products, production processes, management or organization. In the case when the outlays incurred are greater than the effects, it is necessary to consider the elimination of this process or its improvement (Trzeliński et al.,2013). Currently, most of the companies operating on the metal market strive to be able to produce the largest possible amount of the product at the lowest cost of its production. However, to achieve such effects, it is necessary to improve the efficiency of the process and increase its effectiveness. The efficiency of production is the ratio of the current volume of production to the size that is possible to achieve. Thanks to the effectiveness measurements, managers can check to what extent the assumed goals are realized. Enterprises that want to best manage their resources also measure their productivity. This indicator 
allows the assessment of the use of resources during the production of the finished product. In order to obtain satisfactory results in the form of increased efficiency and effectiveness, as well as productivity, enterprises use a combination of a variety of methods and tools. The production processes, as they belong to the basic ones, should be constantly improved. Continuous improvement methodology uses many tools. One of them is, for example, based on the Shewart's linear model (Shewarth, 1939), Deming PDCA cycle (Deming, $1950,1986,1993)$ presented in 1950, whose newer versions have been and are being developed and applied in quality management (Deming 1986, 1993; Anderson et al. 1995; Douglas \& Fredendall 2004 etc.). Of course, in order to achieve the real benefits of continuous improvement of processes, a number of studies have been developed which point to factors to be considered when implementing changes (e.g.: Kaye \& Anderson, 1999; Alhaqbani et al., 2016; Fryer et al., 2007; Sila, 2007, itd.). However, although there are few studies on the impact of process improvement on production costs, they have the character of models ( $\mathrm{Li}$ et al. 2018; Sarkar 2019; Ahire \& Dreyfus 2000) and not specific examples of savings along with an indication of the quality management methods used, as in the case of this study.

\section{CONCLUSSION}

On the basis of the analysis, it can be concluded that the goal of the research has been achieved. Achieving the research objective required identifying areas in the bearing ring production process that would cause problems (defects) and then demonstrating that the implementation of appropriate quality methods and the development of corrective actions based on them could contribute to the elimination or partial reduction of the occurrence of similar defects in the future. In the analyzed case it was decided on the use of quality management tools such as FMEA and 5Why. In order to illustrate the effects of the implemented corrective actions there were estimated: the costs of arising defects, costs of corrective actions, costs of defects after the introduction of corrective actions and savings resulting from the introduction of improvements. This was particularly important from the point of view of the economic situation of the analyzed company and the level of products complained by customers. After analyzing the process and analyzing defects arising at its individual stages, it was found that one of the main reasons for the numerous defects in the tested product were workers' errors, which can be substantiated by their high rotation and lack of appropriate supervision over inexperienced operators. In order to improve the functioning of the production process under examination, it would be reasonable to develop labor standards based on the methods used, which will allow the stability and integrity of the entire bearing production process to be increased thanks to the repeatability and the possibility of obtaining consistently the same process results. The development of standards in indicated areas will also contribute to continuous improvement in accordance with the kaizen philosophy, as the revised process will be included in the standard and will become a step to further improvement. It should also be emphasized that the 
standardization of the process in the examined enterprise cannot be limited only to routine compliance with procedures, but above of all should become a source of improvement of work.

In the case study, after the process analysis of the FMEA process, some observations about the tool itself arise. Namely, it would be reasonable to extend the FMEA analysis to the area where a particular defect was created in the production process. This is essential from the point of view of process efficiency and the speed of elimination of emerging problems. Therefore, the FMEA analysis should be supplemented with information on areas where defects occur during the process. This is very important if the defect in the finished product repeats. Then it is possible to analyze and indicate the stage in which the given defect occurs most frequently. The time of detecting the defect is also important. It should be determined whether the detection of the defect occurred at the stage of production or if the defect was disclosed by the customer.

In summary, it has been shown that the use of such methods of improving the production process as 5WHY and FMEA affects its efficiency. Moreover, it has been shown that this impact is positive (the level of the RPN indicator has been reduced or the previous defect in the production process has been completely eliminated) - thus the $\mathrm{H} 1$ Hypothesis was verified and the specific objective $\mathrm{C} 1$ was achieved. It has also been shown that specific financial benefits were achieved after the changes were introduced, which enabled the verification of the $\mathrm{H} 2$ hypothesis and thus the achievement of the specific objective $\mathrm{C} 2$. Based on the results above, it can be concluded that the proposed changes were the most reasonable, and therefore the specific objective C3 was achieved.

\section{REFERENCES}

Ahire S. L. and Dreyfus P. (2000), The impact of design management and process management on quality: an empirical investigation, Journal of Operations Management, Vol. 18, Issue 5, pp. 549-575, Available at: https://doi.org/10.1016/S0272-6963(00)00029-2 [Accessed 10 Jun 2019].

Alhaqbani A., Reed D. M., Savage B.M. and Ries J., (2016), The impact of middle management commitment on improvement initiatives in public organizations, Business Process Management Journal, Vol. 22 Issue: 5, pp. 924-938, Available at: https://doi.org/10.1108/BPMJ-01-2016-0018 [Accessed 11 Jun 2019].

Anderson J.C., Rungtusanatham M., Schroeder R.G. and Devaraj S., (1995), A path analytic model of a theory of quality management underlying the deming management method: preliminary empirical findings. Decision Sciences 26 (5), pp. 637-658.

Baskiewicz, N. and Kadłubek, M., (2017), Lean Management Tools Used for the Purpose of Production Process Improvement in an Enterprise, Prace Naukowe UE we Wrocławiu 463, pp. 121-131

Deming W.E. (1952), Elementary Principles of the Statistical Control of Quality,; 2nd edition, Nippon Nippon Kagaku Gijutsu Remmei

Deming W.E. (1986), Out of the Crisis, Massachusetts, MIT Press.

Deming W.E. (1993), The New Economics, Massachusetts, MIT Press Ltd.

Douglas T. J., and Fredendall L. D. (2004), Evaluating the Deming management model of total quality in services, Decision Sciences 35 (3), pp. 393-422.

Fryer, K.J., Antony, J. and Douglas, A. (2007), Critical success factors of continuous improvement in the public sector: a literature review and some key findings, The 
TQM Magazine, Vol. 19 No. 5, Available at: doi: 10.1108/09544780710817900 [Accessed 21 May 2019].

llés, B. Cs., Szuda, Cs. And Dunay, A. (2017). Quality and management - tools for continuous and systematic improvement of processes. In B. Cs. Illés (ed.), M. Nowicka-Skowron (ed.), E. Horská (ed.), A. Dunay (ed.) Management and Organization: Concepts, Tools and Applications, Harlow, Pear. Ed. Ltd., pp. 99108, Available

at: http://real.mtak.hu/54693/1/100_Management_and_Organization-Pearson2017j\%C3\%BAn08-DOI_CrossRef-2017j\%C3\%BĀ̄13f.pdf [Accessed 28 Jun 2019].

Kaye, M. and Anderson, R. (1999), Continuous improvement: the ten essential criteria, International Journal of Quality \& Reliability Management, Vol. 16 No. 5, pp. 485509, Available at: doi: 10.1108/02656719910249801 [Accessed 10 May 2019].

Li G., Reimann M. and Zhang W. (2018), When remanufacturing meets product quality improvement: The impact of production cost, European Journal of Operationa IResearch 271, pp. 913-925, Available at: https://doi.org/10.1016/j.ejor.2018.05.060 [Accessed 21 Jun 2019].

Mazur, M., (2016), Assumptions Concept of LEAN Processes in the Organization of the Work on Example the Production of Building Components, Prod. Eng. Arch. 3, No. 4, pp. 41-43

Nowakowska, K. and Ingaldi, M. (2016), Wykorzystanie metody 5W2H do doskonalenia produkcji wentylatorów, Arch. W. Inż. T. 1, 1, pp. 39-41

Rampersad H.K. (2004), Kompleksowa karta wyników. Jak przekształcić zarządzanie, aby postępując uczciwie osiągać doskonałe wyniki, Warszawa, Placet.

Sarkar, B. (2019), Mathematical and analytical approach for the management of defective items in a multi-stage production system, Journal of Cleaner Production, Vol. 218, pp. 896-919, Available at: https://doi.org/10.1016/j.jclepro.2019.01.078 [Accessed 30 May 2019].

Shewhart W.A. (1939), Statistical Method from the Viewpiont of Quality Control, Washington, The Graduate School, The Department of Agriculture.

Sila I. (2007), Examining the effects of contextual factors on TQM and performance through the lens of organizational theory: an empirical study, Journal of Operations Management, Vol. 25 No. 1, pp. 83-109.

Trzeliński S., Adamczyk M. and Pawłowski E. (2013), Procesowa orientacja przedsiębiorstwa. Poznań, Wydawnictwo Politechniki Poznańskiej.

Ulewicz, R. , Nowakowska-Grunt, J. and Jelonek, D., (2015), Performance Evaluation of the Production Control Systems of Push and Pull Type, Appl. Mech. Mat., 795, pp. 235-242.

Ulewicz, R., Mazur, M. and Jelonek, D. (2016), Implementation of logic flow in planningand production control, Manag. Prod. Eng. Rev., 7, No. 1, pp. 89-94 Available at: http://mper.org/mper/images/archiwum/2016/nr1/10-ulewicz.pdf [Accessed 10 Jun 2019].

\begin{abstract}
.
In the paper there was presented the role and importance of choosing appropriate quality management methods in making decisions on implementing corrective actions on the example of a selected metallurgical company. There was presented application of the results of production process improving methods, such as 5 Why and FMEA, to indicate corrective actions. Moreover, it was analyzed whether, after introducing these activities, it was possible to eliminate or limit defects in the production process. For this purpose, the level of the RPN index was recalculated - after the changes were introduced. Furthermore, the costs of defects before and after the introduction of corrective actions were estimated.
\end{abstract}

Keywords: improvement, quality management, process, production 